\title{
GPRC5A wt Allele
}

National Cancer Institute

\section{Source}

National Cancer Institute. GPRC5A wt Allele. NCI Thesaurus. Code C51471.

Human GPRC5A wild-type allele is located within 12p13-p12.3 and is approximately $22 \mathrm{~kb}$ in length. This allele, which encodes retinoic acid-induced protein 3 , is involved in interactions between retinoid acid and G protein signaling pathways. The allele may also play a role in embryonic development and epithelial cell differentiation. 